\title{
Pott's disease and tuberculous psoas abscesses in a patient with acquired immunodeficiency syndrome
}

\author{
Mal de Pott e abscessos tuberculosos de psoas em paciente \\ com síndrome da imunodeficiência adquirida
}
Marcus Vinícius Guimarães de Lacerda ${ }^{1}$, Maria Paula Gomes Mourão ${ }^{1}$ and Celeste Aída Nogueira Silveira ${ }^{1,2}$

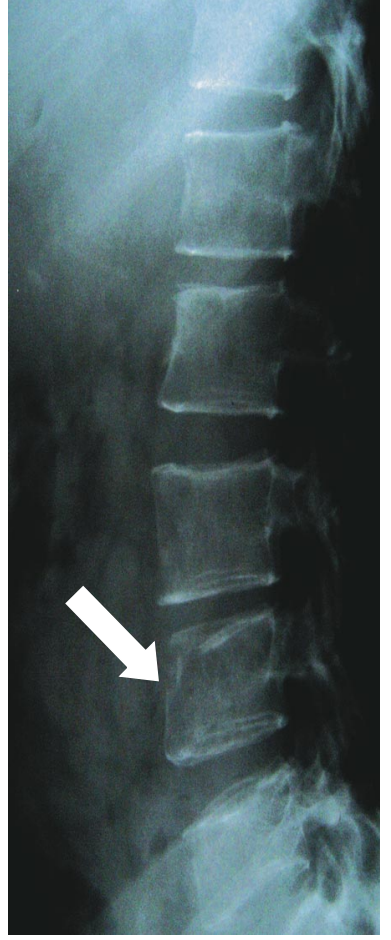

A

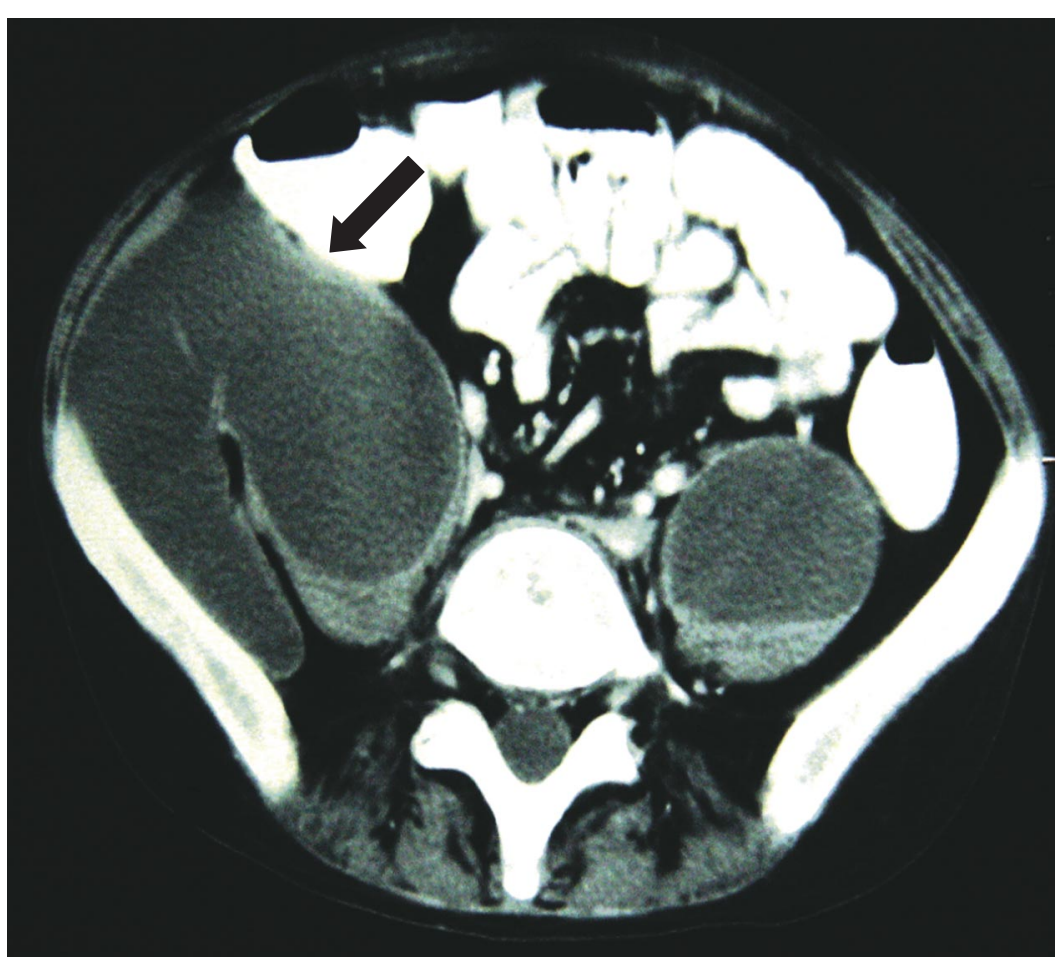

B

1. Núcleo de Medicina Tropical da Faculdade de Medicina da Universidade de Brasília, Brasília, DF, Brasil. 2. Hospital Universitário de Brasília, Universidade de Brasília, Brasília, DF, Brasil.

Address to: Dr. Marcus Vinícius Guimarães de Lacerda. Núcleo de Medicina Tropical/UnB. Caixa Postal 4517, 70919-970 Brasília, DF, Brasil.

e-mail: marcuslacerda@uol.com.br

Rcebido para publicação em 8/10/2003

Aceito em 20/8/2004 
A31-year-old woman with the diagnosis of AIDS for two years, having already developed cytomegalovirus (CMV) retinitis and esophageal candidiasis as opportunistic diseases. She was taking stavudine, lamivudine and efavirenz, plus prophylaxis for CMV and P. carinii. In the six months prior to presentation, she began to complain of lower abdominal pain, diarrhea, weight loss of about $5 \mathrm{~kg}$, anorexia, fever and lower back pain, associated with a decrease in the strength of the lower limbs. A CD4 ${ }^{+} \mathrm{T}$ cell count obtained two months earlier was 60 cells $/ \mathrm{mm}^{3}$. As she could not achieve relief of the back pain with analgesics, she was hospitalized for evaluation. At physical examination, she was thin and pale, with diffuse abdominal pain and tender enlargement of the liver.

Tuberculin skin test was negative. Chest x-ray was normal, but roentgenography of the back revealed lytic lesions of the last lumbar vertebrae, with collapse of the body of L5 (Figure A). Abdominal computed tomography (CT) showed abscesses in the psoas major muscles bilaterally $(12 \times 15 \mathrm{~cm})$, extending to the right to ileo-psoas and iliac muscles (Figure B), with paraaortic and mesenteric lymphadenopathy. The abscess on the right was drained percutaneously under CT guidance. A catheter was inserted after the drainage of $1,000 \mathrm{ml}$ of pus. Cultures of the leftabscess drainage were negative for pyogenic bacteria, butZiehl-Neelsen stains were positive on three different occasions. She was started on rifampin, isoniazid and pyrazinamide, and given tramadol for analgesia. This, with immobilization of the spine, led to clinical improvement. Abdominal CT scan performed two months after starting treatment showed incomplete involution of the abscesses $(5 x 7 \mathrm{~cm})$. A tuberculous abscess of the psoas may develop secondary to spinal tuberculosis, but rarely presents as a primary manifestation.

Paciente de 31 anos, do sexo feminino, com diagnóstico de AIDShá cerca de dois anos, tendo já apresentado como complicações oportunistas coriorretinite por citomegalovírus ( CMV) e candidíase esofágica. Estava, há um ano, em uso de estavudina, lamivudina e efavirenz, e profilaxia para CMVe P. carinii. Nos últimos seis meses, vinha apresentando dor abdominal em região hipogástrica, diarréia, perda ponderal de 5kg, anorexia, febre e lombalgia intensa, associada a diminuição da força nos membros inferiores. A última contagem de linfócitos T CD4 ${ }^{+}$, há dois meses, revelou 60 células $/ \mathrm{mm}^{3}$. Como não conseguia controlar a dor lombar com analgésicos, foi internada para investigação diagnóstica. Encontrava-se, ao exame físico, emagrecida, hipocorada, com dor abdominal difusa e hepatomegalia dolorosa. PPD não-reator. A radiografia simples de tórax foi normal e a radiografia de coluna mostrou lesões líticas das últimas vértebras lombares, com desmoronamento do corpo vertebral de L5 (Figura A). A tomografia computadorizada (TC) abdominal evidenciou abscessos no músculo psoas maior, bilateralmente $(12 \times 15 \mathrm{~cm})$, extendendo-se, à direita, para os músculos íleo-psoas e ilíaco (Figura B) e linfadenomegalia para-aórtica e mesentérica. 0 abscesso à direita foi drenado por via percutânea, orientado por TC. Após a saída de $1.000 \mathrm{ml}$ de secreção purulenta, foi inserido um cateter. A cultura do material drenado foi negativa para bactérias piogênicas e a pesquisa direta de bacilos álcoolácido resistentes (BAAR) foi positiva em três momentos diferentes. Iniciou-se 0 uso de rifampicina, isoniazida e pirazinamida, analgesia regular com tramadol e estabilização da coluna vertebral, com melhora clínica. A TC abdominal realizada dois meses após 0 início do tratamento mostrou involução ainda incompleta dos abscessos ( $5 \times 7 \mathrm{~cm})$. 0 abscesso tuberculoso do psoas geralmente é secundário à tuberculose espinhal, sendo excepcional a forma primária.

\section{REFERENCES}

1. Franco-Paredes C, Blumberg HM. Psoas muscle abscess caused by Mycobacterium tuberculosis and Staphylococcus aureus: case report and review. American Journal of Medical Sciences 321: 415-417, 2001.

2. Huelskamp L, Anderson S, Bernhardt M. TB of the spine: Pott's disease. Orthopaedic Nursing 19: 31-35, 2000.

3. Muckley T, Schutz T, Kirschner M, Potulski M, Hofmann G, Buhren V. Psoas abscess: the spine as a primary source of infection. Spine 28: E106-E113, 2003. 